\title{
Bio-Medical Aspects of Purine Alkaloids
}

\author{
Milan Melnik, Ondrej Sprusansky, Peter Musil \\ Department of Pharmacology and Toxicology, Faculty of Pharmacy, Comenius University, Bratislava, \\ Slovak Republic \\ Email: qmelnik@stuba.sk
}

Received 21 April 2014; revised 31 May 2014; accepted 18 June 2014

Copyright (C) 2014 by authors and Scientific Research Publishing Inc.

This work is licensed under the Creative Commons Attribution International License (CC BY). http://creativecommons.org/licenses/by/4.0/

c) (i) Open Access

\section{Abstract}

This review shortly summarized bio-medical activities of purine alkaloids, caffeine (caf), theophyline (top) and theobromine (tob). Caffeine potentiates the cytotoxicity of a variety of DNA domaging agents. Caffeine increased antitumor activity of some cancerostatic drugs. Caffeine inhibits the carcinogenic activity of cigarette smoke, significantly potentiating the therapeutic effect of acetaminophenol, cyclophosphoramide, enhances lipid oxidation, affects the central nervous system and alters cardiovascular system. Theophyline has expressive anti-inflammatory and antiasthmatic effect, and enhanced mobilization of lipid reduces the brain regional adenylate cyclase activity, facilitates glucose inhibition. Theophyline is muscle relaxant, vasodilator, diuretic and cardiac stimulant. Theobromine increases antitumor activity of adriamycin and doxorubicin, has expressive anti-inflammatory effect and it is classical diureticum. Several examples of caffeine with some organic substrates as well as with copper are also outlined. Increasing activity of the respective drugs in the present of the purine alkaloids can be ascribed to direct interaction as was proved by $\mathrm{X}$-ray data of some caffeine adducts with organic substances as well as $\mathrm{Cu}$ (II) complexes.

\section{Keywords}

Bio-Medical Activity, Caffeine, Purine Alkaloids, Theophyline, Theobromine

\section{Introduction}

Alkaloids are most fascinating organic compounds and many researches pay great attention to them. Purine alkaloids are chosen from the wide range of alkaloids. Purine alkaloids, caffeine, theophyline and theobromine are well known and daily consuming by man. The purine alkaloids possess pharmacological properties as therapeutic agents with a wide variety of activity. In spite of the fact, that from the structural point of view: caffeine (1,3, 7-trimethylxantine), theophyline (1,3-dimethylxantine) and theobromine (3,7-dimethylxantine) are very similar, their bio-medical activities are differing, for example, diuretic effect increases in the order: caffeine $<$ theophy- 
line $<$ theobromine but in the same order the effects on CNS rapidly decrease. A thorough understanding of the geometric and electronic structure of the alkaloids is clearly essential in efforts to clucinadate receptor structure and function on design new pharmaceuticals (Scheme 1).

The reason of the improving bio-medical activity of drugs in the present of the purine alkaloids will be discussed.

\section{Bio-Effect of Purine Alkaloids}

\subsection{Activity of Caffeine (Caf)}

Caffeine may be enhancing the tumoricidal effect of anticancer drugs, resp. DNA—damaging agents and possibly may aid in overcoming natural drug resistance [1]. An ionizing radiation and alkylating agents to potentiate the cytotoxic effects of caf on DNA damage agents [2]. Shoyab [3] proposed that the antitumorigenic effect of caffeine may be related to its ability to inhibit the bonding of active metabolites of carcinogens to cellular DNA. Traganos et al. [4] potentiate the cytotoxicity of a variety of DNA damaging agents presumable by reducing the ability of the cells to repair potentially lethal lesions and may pay a more general role to protecting cells against planar aromatic molecules such as intercalating agents. Therefore caffeine may be considered in designing strategies to modulate the activity of the intercalating drugs in vivo, e.g. in lowering drug toxicity when inadvertently applied at too bright doses [5]. The combination of caffeine with adriamycin can significantly increase the in vivo antitumor activity of this agent without increasing its side effect [6]. The effect of caffeine on adriamycin concentration in the cell plays an important role in the mechanism by which caffeine enhances adriamycin antitumor activity [7]. Also acts as a biochemical modulator of adriamycin [8]. The combination of adriamycin, cis$\mathrm{Pt}\left(\mathrm{NH}_{3}\right)_{2} \mathrm{Cl}_{2}$, and caffeine shoved partial response, and caffeine did not increase the vide effect of anticancer drugs [9]. Caffeine reduced the inhibitory effect of pirarubicin on the incorporation of thymine into DNA and uridine into RNA in cells [10]. Inhibit post replication repair of both UV and chemically induced damage in DNA lesions caused by cis- $\mathrm{Pt}\left(\mathrm{NH}_{3}\right)_{2} \mathrm{Cl}_{2}$ [11]. Induction of DNA fragmentation during $\mathrm{G} 2+\mathrm{M}$ phase by caffeine modulates the cytotoxicity of cis- $\mathrm{Pt}\left(\mathrm{NH}_{3}\right)_{2} \mathrm{Cl}_{2}$ in human osteosarcomic cells (strain) and the antitumor effect of cis-paltinum on transplanted osteosarcoma in athymic since [12] [13]. Caffeine enhanced the antitumor activity of doxorubicin with increasing doxorubicin concentration in tumors in vivo [14]. Caffeine is an inhibitor of DNA repair [15]. Caffeine inhibited the carcinogenic action of cigarette smoke condensate fraction before application [16]. The concomitant consumption of caffeine and cigarette constitutes a higher risk for the developing fetus [17]. Caffeine also potentiates the activity of cyclophosphamide [18]. Caffeine decreased the paracetamol induced hepatic toxicity [19] [20]. Caffeine significantly potentiates the therapeutic potential of acetaminophenol in man [21]. Anderson et al. [22] found that caffeine increases plasma epinephrine, cold increases oxygen consumption and carbohydrate metabolism, while decreasing lipid metabolism, Nishiyama et al. [23] found that caffeine also induced enhanced lipid oxidation as show by the significantly lower respiratory gas exchange ratio and increases in diastolic blood pressure during exercise. The results showed that caffeinated beverages have a potential to be useful supplements to the prescription of exercise for individuals who experience a depressed activity of the autonomic nervous system. Caffeine affects the central nervous system to binding to adenosine receptors, and it has acute and chronic dose dependent, effects on brain fraction [24]. Caffeine also showed the rate of compensatory sleep after sleep deprivation, as indexed by the duration of sleep states and sleep continuity [25]. Caffeine also alters cardiovascular dynamics by augmenting arterial blood pressure [26]. The secretary effect of caffeine may be mainly due to mobilization of calcium from an intracellular calcium pool [27]. High caffeine intake may predispose to cortical bone loss from the proximal femur [28]. Kawaga et al. [29] found, that caffeine facilitates the conversion of allopurinol to oxopurinol and produces high plasma level of oxopurinol in man. Valdes et al. [30] found that when caffeine intake during the gestational and lactation period by their

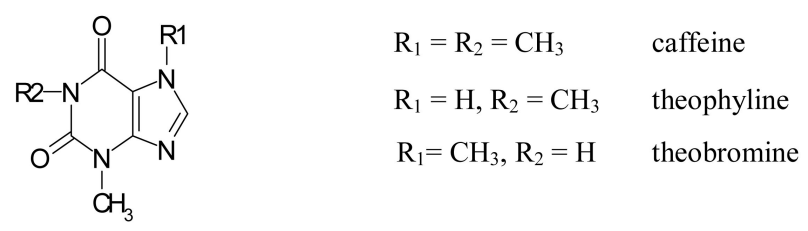

Scheme 1. Structure of purine alkaloids. 
dams and the growing period of pups affect the maxillary components of their offspring. The stimulating action of caffeine depends on the level and source of arousal [31].

\subsection{Activity of Theophyline (Top)}

Biological activity of theophyline also covers wide variety and will be shortly resented. Ito et al. [32] found that the low dose of theophyline exerts an anti-asthma effect through increasing activation of HDAC which is subsequently recruited by corticosteroids to suppress inflammatory genes. Sagara et al. [33] also confirmed that top has anti-inflammatory activity which is pertinent to the treatment of bronchial asthma, when is added to bronchodilator actions. Top decreases the natural sputum eosinophyl chemolactic activity present in asthmatic [34]. Taheuchi et al. [35] found that top is able to induce apoptosis of the IL-3-activated eosinoplies in patient with bronchial asthma, and that its clinical effectiveness may be due to the reduction of inflammatory cells in the airway. Small dose of top inhibited platelet-activating factor receptor mRNA expression in asthma blood lymphatic cells [36]. Changquan et al. [37] used top as therapeutic agent for the treatment of asthma. Pediatric asthma can be treatment by top even at low concentration [37]. Top suppresses that production of proinflammatory cytokines via inhibitor of NF- $\mathrm{KB}$ activation through protection of the IB protein [38]. Top treatment caused a significant increase in renal and muscle carnitine palmitoyltransferase activity [39] [40]. Top also enhanced mobilization of lipid from adipose tissues, which consequently stimulated an increased carnitine transport into the kidney tissues to from fatty acyl-carnitine groups for subsequent oxidation inside the mitochondria [41]. Oral top administration $(100 \mathrm{mg} / \mathrm{kg} / \mathrm{day})$ changes the levels of carnitine in plasma and tissues and increases the activity of carnitine acetyltransferase in the cardiac tissues of rats [42].

Mandal and Poddar found [43] that top under no tolerant condition produced region specific inhibition of adenylate cyclase activity and hence central adenosynergic activity which may be a resultant effect of heterogeneous distribution of extra cellular adenosine receptor (A1 and A2) of different brain regions and also the availability of adenosine for interaction to the intracellular receptor sites (P-site) under this condition. Development of tolerance to top may reduce the brain regional adenylate cyclase activity by increasing the A1 receptor population and hence may stimulate the central adenosynergic activity. Effects of xantine derivatives on phosphatydylcholine secretion in rat were studied by Omura et al. [44]. Top increased the PC secretion the Co-culture of type II pneumocytes and activated eosinophils through the inhibition of phosphodiesterases of the antagonism of adenosine reduced AMP stimulation and facilitated glucose inhibition [45]. Long term top treatment may potentiate or suppress the immune response, depending on the dose, through the tissue (liver/spleen/thymus) specific modulation of adenosine deaminase activity and plasma corticosterone status [46]. Top therapy at optimal doses my not exert adverse side effects on bone homeostasis, but patients receiving supratherapeutic doses of top should be under close exams, in order to periodic future bone mass status [47] Heparin and top in the medium are effective in activating metabolic enzymes, maintaining longer sperm mobility, and efficiently inducing hyper activated sperm even of the sperm of asthenozoospermia [48]

Top increased serum glucocorticoid levels in a dose-dependent manner [49] top used as a muscle relaxant or vasodilator [50]. Top is also effective as a diuretic and cardiac stimulant [51]. Top has a high ulcer score, increase the development of dental caries and this effect may be related to organism, alternation of salivary components [52].

\subsection{Activity of Theobromine (Tob)}

Tob inhibited adriamycin efflux in vitro, increased the antitumor activity of adriamycin and the concentration of adriamycin in tumors [8]. Tob increased the concentration of adriamycin in the tumor without any effects on that in the heart and the liver [53]. Tob inhibited the doxorubicin efflux from tumor cells, increased the doxorubicin concentration in a tumor, and enhanced the antitumor effect of doxorubicin [54]. Tob greatly suppressed urethane-induced tumorigenesis and teratogenesis, whereas top did not [55]. Tob as well as top produced high antiinflammatory activity against acute inflamation induced by acetic acid while caf showed no significant effect [56]. Tob and caf differentiated normally developing somniferous cords made up of Sertoli and germ cells, soon followed by the differentiation of functionally active Leyding cells appearing in the newly formed interstitum [57]. The ratio of tob/caf has effect on hepatic human flavin monooxygenase 3 activity [58]. Tob significantly increased the mouse's ambulatory activity [59]. 


\section{Interactions of Caffeine with Copper}

It is well known, that caffeine possessing pharmacological behaviors as a therapeutic agent with analeptic activity. Several crystal structures of caffeine with organic substrates have been determined, 5-chlorosalicylic acid [60], barbital [61] [62] and also the hydrochloridedihydrate [63]. A few crystal structures of copper (II) complexes with caffeine have been also described. In two examples triaqua (caffeine) nitratocopper (II) nitrate [64] and aqua (caffeine) dichlorocopper (II) [65], the copper(II) atoms are five coordinated. In our lab was prepared di (caffeine) tetrakis (naproxenato) dicopper (II) complex [66]. The compound is binuclear with square pyramidal geometry at each copper(II) centre. Similar binuclear structure of di (caffeine) tetrakis (2-bromopropionato) dicopper (II) [67] as those in [66] was obtained. In copper(II) complexes the caffeine directly coordinated to $\mathrm{Cu}(\mathrm{II})$ atom via $\mathrm{N}$ donor atom.

It was found [68] that the copper(II) carboxylates and their caffeine adducts exhibit considerable biological activity especially against bacteria $\mathrm{G}^{+}\left(\mathrm{S}\right.$. aureus) than that against bacteria $\mathrm{G}^{-}(\mathrm{E}$. coli $)$. The complexes have also caused an increase of inhibition activity against model fungi [69]. For the purpose indicating mechanism of action of $\mathrm{Cu}(2-\mathrm{MeSnic})_{2}(\text { nia })_{2}\left(\mathrm{H}_{2} \mathrm{O}\right)_{2}$ with biosynthesis of nucleic acids and proteins has been monitored [67]. Effect of copper(II) carboxylates and their caffeine adducts on glycolysis respiration processes and cell membranes of the Ehrlich ascite carcinoma are in progress now.

\section{Conclusions}

This review shortly summarized bio-medical activities of purine alkaloids. Caf potentiates the cytotoxicity of a variety of DNA damaging agents. The carcinogenic activity of cigarette smoke was inhibited. The cytotoxicity of some cancerostatic drugs, for example, cisplatin, pirarubicin, adriamycin, was enhanced. Caf decreases the paracetamol-induced hepatic toxicity, significantly potentiating the therapeutic effect of acetaminophenol, cyclophosphoamide, enhances lipid oxidation, affects the central nervous system and also alters cardiovascular system.

Top has expressive anti-inflammatory and anti-asthmatic effect, enhances mobilization of lipid, has an influence on the levels of carnitine in plasma, reduces the brain regional adenylate cyclase activity, participates glucose inhibition and suppresses the immune response. Top increases serum glucocorticoide level, is muscle relaxant, vasodilator, diuretic and cardiac stimulant, and has high ulcer score and development of dental caries.

Tob increases antitumor activity of adriamycin and doxorubicin, and suppresses urethane. It is classical diuretic and expressive anti-inflammatory effect. Bio-medical activity of the respective drugs in the present of the purine alkaloids can be ascribed to the direct interaction between the drugs and the alkaloids via the N-donor atom.

\section{Acknowledgements}

The authors wish to thanks to OPRaD funded by the ERDF (ITMS 26240220071) for financial support.

\section{References}

[1] Tomita, K. and Tsuchija, H. (1989) Caffeine Enhancement of the Effect of Anticancer Agents on Human Sarcoma Cells. Cancer Science, 80, 83-88. http://dx.doi.org/10.1111/j.1349-7006.1989.tb02249.x

[2] Traganos, F., Kapucinski, J., Gong, J., Ardelt, B. and Darzynkiewicz, R.J. (1993) Caffeine Prevents Apoptosis and Cell Cycle Effects Induced by Camptothecin or Topotecan in HL-60 Cells. Cancer Research, 53, 4613-4618.

[3] Shoyab, M. (1979) Caffeine Inhibits the Binding of Dimethylbenz(a)anthracene to Murine Epidermal Cells DNA in Culture. Archives of Biochemistry and Biophysics, 196, 307-310. http://dx.doi.org/10.1016/0003-9861(79)90582-4

[4] Traganos, F., Kamiska-Eddy, B. and Darzynkiewicz, Z. (1991) Caffeine Reverses the Cytotoxic and Cell Kinetic Effects of Novantrone(mitoxantrone). Cell Proliferation, 24, 305-319. http://dx.doi.org/10.1111/j.1365-2184.1991.tb01159.x

[5] Traganos, F., Kapucinski, J., Darzynkiewicz, Z. (1991) Caffeine Modulates the Effects of DNA-intercalating Drugs in Vitro: A Flow Cytometric and Spectrophotometric Analysis of Caffeine Interaction with Novantrone, Doxorubicin, Ellipticine, and the Doxorubicin Analogue AD198. Cancer Research, 51, 3682-3689.

[6] Sadzuka, Y., Machizuki, E. and Tatino, Y. (1993) Caffeine Modulates the Antitumor Activity and Toxic Side Effects of Adriamycin. Cancer Science, 84, 348-353. http://dx.doi.org/10.1111/j.1349-7006.1993.tb02877.x

[7] Sadzuka, Y., Machizuki, E. and Tatino, Y. (1995) Mechanism of Caffeine Modulation of the Antitumor Activity of 
Adriamycin. Toxicology Letters, 75, 39-49. http://dx.doi.org/10.1016/0378-4274(94)03154-Y

[8] Sadzuka, Y., Iwazaki, A., Miyagshima, Y., Nozawa, Y. and Hirota, S.J. (1995) Caffeine-Biochemical Modulator of Axdriamycin. Cancer Science, 86, 594-599. http://dx.doi.org/10.1111/j.1349-7006.1995.tb02439.x

[9] Tomita, K., Tsuchiya, H. and Sasaki, T. (1989) The Combination Cis-Platin, Adriamycin and Caffein and Wide Effect Antitumor activity. Gan to Kagater Rycho, 16, 576-584.

[10] Furusawa, S., Malkawa, L., Fujimura, T., Takayanage, Y. and Sasaki, K. (1993) Influence of Caffeine on Effect of Pirarubicin. Research Communications in Substance Abuse, 14, 179-192.

[11] Roberts, J.J. (1981) Damage in DNA by Cis-Platin. Advances in Inorganic Biochemistry, 3, 273-276.

[12] Shinomiya, N., Shinimiya, M., Wakaiyama, H., Katsura, Y. and Rokutanda, M. (1994) Enhancement of CDDP Cytotoxicity by Caffeine Is Characterized by Apoptotic Cell Death. Experimental Cell Research, 210, 236-242. http://dx.doi.org/10.1006/excr.1994.1035

[13] Tomita, A. and Tsuchiya, H. (1989) Cytotoxicity of Cis-Platin in the Presence of Caffeine. Clinical Therapeutics, 11, 43-52.

[14] Sadzuka, Y., Egawa, Y., Savanish, H., Miyamoto, K. and Sonobe, T. (2002) Effects of Xanthine Derivatives on the Influx and Efflux of Doxorubicin in P388 and DOX-Resistant P388 Leukemia Cells. Toxicology Letters, 135, 137-144. http://dx.doi.org/10.1016/S0378-4274(02)00227-8

[15] Van der Berg, H.W., Favol, H.N.A. and Roberts, J.J. (1977) Caffeine as Inhibition of DNA Repain. Journal of Hematology \& Oncology, 7, 349-373.

[16] Rothwell, A. (1974) Dose-Related Inhibition of Chemical Carcinogenesis in Mouse Skin by Caffeine. Nature, 252, 69-70. http://dx.doi.org/10.1038/252069a0

[17] Beaulac-Baillargeon, L. and Desrosiers, C. (1987) Caffeine-Cigarette Interaction on Fetal Growth. American Journal of Obstetrics \& Gynecology, 157, 1236-1240. http://dx.doi.org/10.1016/S0002-9378(87)80301-0

[18] Gaudin, D. and Yielding, K.L. (1969) Response of a "Resistant" Plasmacytoma to Alkylating Agents and X-Ray in Combination with the Excision Repair Inhibitors Caffeine and Chloroquine. Proceedings of the Society for Experimental Biology and Medicine, 131, 1413-1416. http://dx.doi.org/10.3181/00379727-131-34119

[19] Rainska-Giezek, T. (1995) Paracetamol. Roczniki Pomorskiej Akademii Medycznej Im. Gen. Karola Swierczewskiego W Szczecinie, 41, 69-84.

[20] El-Bassiony, S.F., Abo-Hashim, N., Sirag, S.M. and El-Ghazaly, Y. (1995) Influence of Caffeine on Paracetamol Induced Hepatotoxicity in Rats. Journal of Environmental Sciences (Mansoura, Egypt), 10, 233-242.

[21] Iqbal, N., Ahmad, B., Janbaz, K.H., U1 Hassan Giland, A. and Sarfeuaz, K. (1995) The Effect of Caffeine on the Pharmacokinetics of Acetaminophen in Man. Biopharmaceutics \& Drug Disposition, 16, 481-487. http://dx.doi.org/10.1002/bdd.2510160606

[22] Anderson, E.D. and Hickey, S. (1994) Effects of Caffeine on the Metabolic and Catecholamine Responses to Exercise in 5 and 28 Degrees. Medicine and Science in Sport and Exercise, 26, 453-458. http://dx.doi.org/10.1249/00005768-199404000-00009

[23] Nishiyama, Y., Ikeda, T., Takamutsu, M., Kiso, Y., Shibata, H., Fusheki, T. and Moritane, T. (2002) Influence of Caffeine Ingestion on Autonomic Nervous Activity during Endurance Exercise in Humans. European Journal of Applied Physiology, 87, 475-480. http://dx.doi.org/10.1007/s00421-002-0678-1

[24] Leberman, H.R., Fine, B.J., Kobrick, J.L. and John, J.D.E. (1993) Study of Effects Caffeine on Central Nervous System. AGARD Conference Proceedings, 533.

[25] Wurts, S.W. and Edgar, D.M. (2000) Caffeine during Sleep Deprivation: Sleep Tendency and Dynamics of Recovery Sleep in Rats. Pharmacology, Biochemistry and Behavior, 65, 155-162. http://dx.doi.org/10.1016/S0091-3057(99)00173-2

[26] Engels, H.J., Wirth, J.C., Celek, S. and Dorsey, J.L. (1999) Influence of Caffeine on Metabolic and Cardiovascular Functions during Sustained Light Intensity Cycling and at Rest. International Journal of Sport Nutrition, 9, 361-370.

[27] Lim, D.Y., Lee, J.M., Kim, W.S., Kim, S.B., Lee, E.H., Lee, J.B. and Ko, S.T. (1991) Studies on Secretion of Catecholamine Evoked by Caffeine from the Isolated Perfused Rat Adrenal Gland. Archives of Pharmacal Research, 14, 55-67. http://dx.doi.org/10.1007/BF02857816

[28] Su, J.Y. (1991) Influence of Caffeine, $\mathrm{Ca}^{2+}$, and $\mathrm{Mg}^{2+}$ on Ryanodine Depression of the Tension Transient in Skinned Myocardial Fibers of the Rabbit. Pflügers Archiv: European Journal of Physiology, 421, 1-6.

[29] Kagawa, Y., Mayumi, N., Higashigawa, S., Katsuda, K., Kakito, M., Inagaki, S., Ohsugi, H., Sumida, K., Sakurai, M. and Edobashi, T. (1992) Caffeine Facilitates the Conversion of Allopurinol to Oxipurinol. Mie Medical Journal, 42, 203-207.

[30] Valdes, M., Shaye, R., Joseph Jr., F. and Nakamoto, T. (1992) The Effects of Caffeine on the Maxillary Composition 
in the Newborn Rat. Calcified Tissue International, 50, 165-168. http://dx.doi.org/10.1007/BF00298795

[31] Kruk, B., Chmura, J., Krzeminski, K., Ziemba, A.W., Nazar, K., Pekkarinen, H. and Kaciuba-Uscilko, H. (2001) Influence of Caffeine, Cold and Exercise on Multiple Choice Reaction Time. Psychopharmacology, 157, 197-201. http://dx.doi.org/10.1007/s002130100787

[32] Ito, K., Lim, S., Caramori, G., Cosiio, B., Chung, K.F., Adcock, T.M. and Barnes, P.J. (2002) A Molecular Mechanism of Action of Theophylline: Induction of Histone Deacetylase Activity to Decrease Inflammatory Gene Expression. Proceedings of the National Academy of Sciences of the United States of America, 99, 8921-8926.

[33] Sagara, H., Makino, S., Chibana, N., Ota, M., Holgate, S.T., Church, M.K. and Fukuda, T. (2001) Theophyline at Therapeutic Concentrations Inhibits NF- $\mathrm{KB}$ Activation in Human Lung Mast Cells. International Archives of Allergy and Immunology, 124, 371-375. http://dx.doi.org/10.1159/000053761

[34] Louis, R., Bettiol, J., Cataldo, D., Sele, J., Henquet, M. and Rademecker, M. (2000) Effect of a 4-Week Treatment with Theophylline on Sputum Eosinophilia and Sputum Eosinophil Chemotactic Activity in Steroid-Naive Asthmatics. Clinical \& Experimental Allergy, 30, 1151-1160. http://dx.doi.org/10.1046/j.1365-2222.2000.00867.x

[35] Takeuchi, M., Hayakawa, A., Takagi, K., Hiramatsu, K., Shimizu, Y., Matsumoto, S., Hiramatsu, T., Ito, Y., Kume, H., Suzuki, R. and Yamaki, K. (1999) Theophylline Induces Apoptosis of the IL-3 Activated Eosinophils of Patients with Bronchial Asthma. Apoptosis, 4, 461-468. http://dx.doi.org/10.1023/A:1009656527168

[36] Lin, Z.T., Huang, H.L., Zhao, L.N., Yu, Q.S. and Zhong, N.S. (1998) Inhibited of Theophylline on Factor (PAF) in Asthma. Zhongguo YaoYau-Lixue Tongbao, 14, 30-32.

[37] Blake, K. (1999) Theophylline. In: Murphy, S. and Kelly, H.W., Eds., Pediatric Asthma, MarcelDekker, New York, 363-431.

[38] Ichiyama, T., Hasegawa, S., Matsubara, T., Hayashi, T. and Furukawa, S. (2001) Theophylline Inhibits NF-Kappa B Activation and I Kappa B Alpha Degradation in Human Pulmonary Epithelial Cells. Naunum-Schmiedeberg's Archieves of Pharmacology, 364, 558-561.

[39] Alhomida, A.S. (2001) Oral Theophylline Changes Renal Carnitine Palmitoyltransferase Activity in Rats. Archives of Medical Research, 32, 394-399. http://dx.doi.org/10.1016/S0188-4409(01)00299-5

[40] Alhomida, A.S. (2001) Evaluation of Theophylline-Stimulated Changes in Carnitine Palmitoyltransferase Activity in Skeletal Muscle and Liver of Rats. Journal of Enzyme Inhibition and Medicinal Chemistry, 16, 177-183. http://dx.doi.org/10.1080/14756360109162367

[41] Alhomida, A.S. (1998) Evaluation of the Impact of Theophylline Treatment on Carnitine Acetyltransferase Activity in RAT Kidney. In Vivo, 12, 553-558.

[42] Alhomida, A.S. (1999) Study of Theophylline on the Level of Carnitine in the Cardiac Tissues of Rats. Journal of Biochemistry Molecular Biology and Biophysics, 2, 273-280.

[43] Mandal, M. and Podar, M.K. (2001) Brain Regional Adenylate Cyclase Activity: Effect of Theophylline under Nontolerant and Tolerant Conditions. Biogenic Amines, 16, 251-268.

[44] Okumura, M., Kai, H., Shinozawa, S., Isohama, Y., Takahama, K. and Miyata, T. (1997) Effects of Xanthine Derivatives on Phosphatidylcholine Secretion in Rat Type II Pneumocytes in the Presence of Activated Eosinophils. Japanese Journal of Pharmacology, 75, 425-432.

[45] Faang, N. and Nuttall, F.Q. (1997) The Effect of Caffeine and Caffeine Analogs on Rat Liver Phosphorylase a Activity. Journal of Pharmacology and Experimental Therapeutics, 280, 1312-1318.

[46] Bandyopadhyay, B.C. and Poddar, M.K. (1997) Theophylline-Induced Changes in Mammalian Adenosine Deaminase Activity and Corticosterone Status: Possible Relation to Immune Response. Methods and Findings in Experimental and Clinical Pharmacology, 19, 181-184.

[47] Oner, P., Gurdol, F., Oner-Iyidon, Y., Kolanci, C. and Buyukozturk, S. (1999) Evaluation of the Effect of Low-Dose Oral Theophylline Therapy on Some Bone Turnover Markers and Serum Prolidase I Activity in Mild Asthmatics. Pharmacological Research, 40, 189-193. http://dx.doi.org/10.1006/phrs.1999.0486

[48] Kawakami, E., Arai, T. and Nakamura, U. (1999) Effects of Medium Containing Heparin and Theophylline on Capacitation and Metabolic Enzyme Activities of Ejaculated spermatozoa from Dogs with Asthenozoospermia. Animal Reproduction Science, 54, 251-259. http://dx.doi.org/10.1016/S0378-4320(98)00158-4

[49] Sako, J., Hori, S. and Kawamura, M. (1998) Effect of Theophylline, Caffeine and Dimethylxanthines on Endogenous Glucocorticoid Levels in Mice. A Possible Mechanism of Anti-Inflammatory Activity of Theophylline. Pharmacy and Pharmacology Communications, 4, 499-501.

[50] Ebisuzaki, Y., Boyle, P.D. and Smith, J.A. (1997) Methylxanthines. I. Anhydrous Theophylline. Acta Crystallographica Section C, Crystal Structure Communications, 53, 777-779. http://dx.doi.org/10.1107/S0108270197001960

[51] Nakao, S., Fuji, S., Sakaki, T. and Tomita, K. (1977) Crystal and Molecular-Structure of 2-1 Molecular-Complex of 
Theophylline with Phenobarbital. Acta Crystallographica Section C, Crystal Structure Communications, 33, 13731376.

[52] Del Bartolo Ruenis, A.P., Rosalen, P.L., Volpato, C.M. and Gropo, F.C. (2000) Effects of Caffeine and Theophylline on the Development of Dental Caries in Rats. Biological \& Pharmaceutical Bulletin, 23, 339-343. http://dx.doi.org/10.1248/bpb.23.339

[53] Sadzuka, Y., Iwazaki, A. and Hirota, S. (1998) Effects of Methylxanthine Derivatives on Antitumor Activity and Toxic Side Effect of Adriamycin Induced by Inhibition of DNA Biosynthesis. Yakugaku Zasshi, 118, 179-187.

[54] Kakuyama, A. and Sadzuka, Y. (2001) Effect of Methylxanthine Derivatives on Doxorubicin Transport and Antitumor Activity. Current Drug Metabolism, 2, 379-395. http://dx.doi.org/10.2174/1389200013338270

[55] Nomura, T. (1983) Comparative Inhibiting Effects of Methylxanthines on Urethan-Induced Tumors, Malformations, and Presumed Somatic Mutations in Mice. Cancer Research, 43, 1342-1346.

[56] Hosseinzadeh, H. and Deghan, R. (1999) Anti-Inflammatorynactivity of Purine Alkaloids. Pharmaceutical and Pharmacological Letters, 9, 18-19.

[57] Pollard, I., Locquet, O., Odette, S., Solvar, A. and Magre, S. (2001) Effects of Caffeine and Its Reactive Metabolites Theophylline and Theobromine on the Differentiating Testis. Reproduction, Fertility and Development, 13, 435-441. http://dx.doi.org/10.1071/RD01018

[58] Rettie, E.A. and Dieter, H.D. (2000) Can Caffeine Metabolism Be Used as an In-Vivo Probe for Human FlavinContaining Monooxygenase Activity? Pharmacogenetics, 10, 275-277. http://dx.doi.org/10.1097/00008571-200004000-00010

[59] Kuribara, H., Asahi, T. and Tadokoro, S. (1992) Behavioral Evaluation of Psycho-Pharmacological and Psychotoxic Actions of Methylxanthines by Ambulatory Activity and Discrete Avoidance in Mice. Journal of Toxicological Sciences, 17, 81-90. http://dx.doi.org/10.2131/jts.17.81

[60] Shefter, E. (1968) Structural Studies on Complexes II. Crystal and Molecular Structure of a 1:1 Caffeine and 5-Chlorosalicyclic Acid Complex. Journal of Pharmaceutical Sciences, 57, 1163-1168. http://dx.doi.org/10.1002/jps.2600570715

[61] Craven, B.M. and Gartland, G.L. (1974) The 2:1 Crystal Complex of 5,5-diethylbarbituric Acid (Barbital) and Caffeine. Acta Crystallographica Section B, 30, 1191-1195. http://dx.doi.org/10.1107/S0567740874004559

[62] Mercer, A. and Trotter, J. (1978) Crystal and Molecular Structure of 1,3,7-trimethyl-2,6-Purinedione Hydrochloride Dihydrate (Caffeine Hydrochloride Dihydrate). Acta Crystallographica Section B, 34, 450-453. http://dx.doi.org/10.1107/S0567740878003337

[63] Cingi, M.B., Villa, A.C., Manfredotti, A.G. and Guastini, C. (1972) Crystal Structure of Caffeine-Hydrochloride Dihydrate. Crystal Structure Communications, 1, 363-365.

[64] Bondoli, G., Biagini, M.C., Clemente, D.A. and Rizzardi, G. (1976) Preparation, Crystal and Molecular Structure of aquadichlorocaffeinecopper(II). Inorganica Chimica Acta, 20, 71-78. http://dx.doi.org/10.1016/S0020-1693(00)94093-3

[65] Koman, M., Melnik, M., Moncol, J. and Glowiak, T. (2000) Caffeine in Copper(II) Complexes: Crystal and Molecular Structure of di(caffeine)tetrakis(naproxenato) dicopper(II). Inorganic Chemistry Communications, 3, 489-492. http://dx.doi.org/10.1016/S1387-7003(00)00122-2

[66] Valach, F., Melnik, M., Bernardinelli, G. and From, K.M. (2006) A Structural Study of Copper(II) Carboxylates: Crystal Structure and Physical Characterisation of $\left.\left[\mathrm{Cu}_{2}(2 \text {-bromopropanoato })_{4} \text { (caffeine) }\right)_{2}\right]$. Journal of Chemical Crystallography, 36, 571-580. http://dx.doi.org/10.1007/s10870-006-9102-8

[67] Segla, P., Miklos, D. and Melnik, M. (2010) Structures, Physico-Chemical Properties and Biological Activities of Copper(II) Pyridinecarboxylates. Nova Science Publishers, Inc., New York, 1-82.

[68] Dudová, B., Hudecová, D., Pokorný, R., Mikulášová, M., Palicová, M., Segl’a, P. and Melník, M. (2001) Copper Complexes with Bioactive Ligands. Part I-Antimicrobial Activity, Folia Microbiologica, 46, 379-384. http://dx.doi.org/10.1007/BF02814425

[69] Dudova, B., Hudecova, D., Pokorny, R., Mickova, M., Palicova, M., Segla, P. and Melnik, M. (2002) Copper Complexes with Bioactive Ligands-Part II-Antifungal Activity. Folia Microbiologica, 47, 225-229.

http://dx.doi.org/10.1007/BF02817642 